Aquestão
datécnica

eO

Caminho

papa a

-

inquagem

natilosofia

de Martin

Heidegger
A questão da

técnica e o

caminho para

a linguagem

na filosofia

de Martin

Heidegger 


\title{
A questão da técnica e 0
}

\section{caminho para a linguagem na}

\section{filosofia de Martin Heidegger}

\author{
Izabella Corrêa Magalhães Coutinho \\ Universidade Federal de São João del-Rei
}

RESUMO: Ao investigar aquele que seria o aspecto fundamental da técnica moderna, Martin Heidegger explicita o nexo que liga o fenômeno da técnica à metafísica, à ciência, à linguagem e ao destino e futuro do Ocidente. Conduzido através do sentido e verdade do Ser, o filósofo compreende a essência da técnica como desencobrir, trazendo à luz o que soa através das palavras gregas tékhne, poiésis e alétheia. Nessa compreensão, a questão da técnica se orienta para o âmbito mais originário da linguagem. Considerando os escritos de Heidegger pós-1930, sobretudo A questão da técnica, publicado em 1954, Língua de tradição e língua técnica, de 1962, e Para quê poetas?, de 1946, o objetivo deste texto é percorrer o caminho de tal orientação, investigando como se expressam e se estreitam as relações entre a essência da técnica e os sentidos de verdade, destino, língua e linguagem no pensamento de Heidegger. No curso desse exame - da questão da técnica à linguagem - deve ser possível retomar o que nos diz o filósofo a respeito da tarefa de pensar o homem contemporâneo na dominância da técnica e suas tecnologias. PALAVRAS-CHAVE: técnica; verdade; linguagem; Heidegger. 
De acordo com as ideias de Martin Heidegger (HEIDEGGER, 1978; 1991), a filosofia, desde Sócrates, Platão e Aristóteles, se realiza como Metafísica e se desenvolve através da pergunta pelo ser do ente ou pela totalidade do ente, concentrando-se absolutamente nesse domínio ôntico, ou seja, que diz respeito às coisas que são, que se refere ao ente e seu modo de ser. Segundo o filósofo, a metafísica se desdobra ora como pesquisa do ente como tal, ora como teologia ou investigação do ente supremo ou primeiro, mas não ainda como ontologia fundamental, ou seja, como compreensão do ser do ente a partir do Ser ele mesmo. ${ }^{1}$

Para Heidegger, a metafísica como "núcleo" e "centro" decisivo da filosofia (HEIDEGGER, 1978, p. 47) até Nietzsche - o último metafísico terminou por obscurecer o sentido do Ser, tornando-se história do esquecimento do Ser (Seinvergessenheit), realçado a partir das determinações do ente. A filosofia ocidental se cumpriria como a história desse esquecimento, cujo auge e acabamento configuram a modernidade sob a dominância da técnica. Nesse sentido, o projeto heideggeriano propõe um passo atrás para demonstrar como se torna possível o próprio discurso metafísico,

1. Está em questão o que Heidegger chama a diferença ontológica obscurecida na metafísica, isto é, a diferença fundamental de sentido entre o ser do ente e o Ser ele mesmo. Aqui não é o caso de adentrar a argumentação de Heidegger, apenas assinala-se que, a partir desse ponto e ao longo do texto, manteremos essa grafia (Ser) para sugerir a distinção de sentido mencionada. A questão da diferença ontológica é abordada diretamente por Heidegger em A essência do fundamento, de 1929. 
procurando revelar como a noção da verdade passa a equivaler-se rigidamente à verdade do ente, permanecendo aí velada a tematização do sentido e verdade do Ser ele mesmo.

A tradição em que nos firmamos se guiou pela pergunta "que há com o ente?” (HEIDEGGER, 1978, p. 60). Todavia, o filósofo sugere que a pergunta a se fazer é: "por que há simplesmente o ente e não antes o Nada?" (HEIDEGGER, 1978, p. 60). Formulada desse modo, a questão se desdobra em torno do fundamento do ente, isto é, do ser-ente. Ainda que de maneira ensimesmada, se assim podemos dizer, é essa pergunta pelo ser do ente que deverá nos conduzir de volta à pergunta que deve ser posta em primeiro lugar: "o que há com o ser?" (HEIDEGGER, 1978, p. 60). Para o filósofo, nos parece ainda demasiada insólita a procura pelo ser, pois esse não está disponível aqui ou ali como os entes estão. Quem, então, poderia apreender o Ser? Para Heidegger, é essa desconfiança o que nos teria lançado na corrida pelo ente, fundamentando a decadência do homem moderno. Resta daí a formulação essencial: "O Ser é uma simples palavra e sua significação um vapor, ou constitui o destino espiritual do Ocidente?” (HEIDEGGER, 1978, p. 64).

A tarefa de Heidegger, portanto, é "mostrar, que e em que medida nossa compreensão do Ser possui uma determinação própria e tem a sua orientação disposta pelo Ser mesmo" (HEIDEGGER, 1978, p. 115). A cada manifestação do ente, a cada vez que usamos acertadamente o "é", é o Ser que se nos abre numa diversidade de modos. Para Heidegger, de fato, em nossa época histórica terminamos por atribuir de imediato à palavra ser um sentido de indiferenciação, como uma palavra que designa algo indeterminado, tendo um sentido vazio e uma "significação flutuante" (HEIDEGGER, 1978, p. 101). Entretanto, se analisamos bem, poderemos certamente duvidar dessa vacuidade, pois não há quem não compreenda ser, de 
modo que uma significação ou outra sempre nos vem através da palavra. Isso que sempre nos ocorre sobre esta palavra, segundo Heidegger, é o que nos impele ao pensamento sobre o destino espiritual do Ocidente, isto é, sobre sua história, entendendo destino e história no horizonte da temporalidade originária que traduz o ser do homem no modo de sua existência fática. A temporalidade que traduz o homem deixa ver a compreensão de Ser (2015). Sobre isso diz a investigação da obra maior, Ser e tempo, publicada em 1927.

Nesse sentido, através do exame acerca de quem é o homem - cujo modo de ser temporal deixa ver a compreensão de Ser -, Heidegger nos apresenta uma interpretação posterior a Ser e tempo que aqui parece de maior relevância do ponto de vista de nossa discussão acerca da técnica. Para falar a propósito do homem grego, cujo modelo anima o modo de ser ocidental, Heidegger interpreta os versos da tragédia Antígona², de Sófocles (HEIDEGGER, 1978; 1996). A partir da experiência do homem grego, o filósofo apresenta certos elementos fundamentais a respeito do próprio homem e da técnica, elementos que terminaram obscurecidos na metafísica e ciência modernas e ainda mais ofuscados no desgaste da língua.

Pensando no homem grego, algo fundamental deve ser destacado a respeito do sentido da palavra tékhne. Primeiramente, tal sentido pode ser vislumbrado na referência mútua entre o significado de tékhne e díke. Díke é traduzida por Heidegger como "juntura" ou conjuntura (HEIDEGGER, 1978, p. 185), uma disposição e destinação que o vigor do Ser impõe. O Ser, aqui identificado com a physis como vigor que impera, é conjuntura que

2. Trata-se, sobretudo, da interpretação dos versos 332-333 cantados na primeira entrada do coro: " $\pi 0 \lambda \lambda \dot{\alpha}$

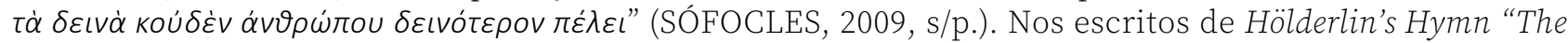


estranho; ver na parte II, o parágrafo 12, The meaning of $\delta \varepsilon \iota v o ́ v$. 
dispõe os entes, é díke, a força mesma do vigor do Ser. Tékhne é a instauração que impõe esse vigor, de modo que a tékhne como nós a concebemos, modernamente, termina se impondo sobre dike. Na busca da totalidade do ente, o pôr em obra da tékhne pretende assegurar a instauração do vigor para si, afirmando e confirmando o ser como acontecer histórico, como configuração epocal da instauração violenta do vigor, isto é, como técnica.

Heidegger nos diz que essa correferência entre a força do vigor e a instauração violenta de vigor, ou seja, entre dike e tékhne, é propriamente o elemento que constitui o acontecer do homem como o mais estranho, tal como nos aparece nos versos de Sófocles. Está em jogo para a existência do humano os efeitos dessa correferenciação entre o Ser e o próprio ente que é. Interpretando a palavra dike com o sentido que assinala o Ser, Heidegger se vale da leitura de Anaximandro, Heráclito e Parmênides. Este último, a partir de seu Poema, teria entendido a palavra díke como a deusa que guarda as chaves dos caminhos do Ser, da aparência ou da dóxa, e do Nada ou do não-Ser. Nas palavras de Heidegger, assim como Parmênides já nos teria dito, como díke, "o Ser é a chave do ente em sua articulação" (HEIDEGGER, 1978, p. 188), isto é, em seu ser, aparecer e não-ser; díke coloca-se, portanto, em referência à tékhne na medida em que esta última se nos destina, por fim, como instauração violenta do vigor do Ser, como desocultamento, no modo da história, do poder-pôr em obra do Ser no ente que é o homem.

Assim, em Ser e tempo vemos a questão da técnica se embrenhando no caráter de utilidade, instrumentalidade, manualidade que percorre toda a explicação fática da estrutura da existência do ser-aí do homem, o Da-sein heideggeriano, que se realiza como um poder-ser próprio em meio às coisas, objetos e utensílios com as quais se engaja, lida e se compromete no modo da existência. Como se vê, compreendida a partir do modo de 
realização do homem, a técnica já aparece tematizada por Heidegger desde seus primeiros trabalhos, ainda que de maneira mais ou menos difusa, movimentando-se como questão essencial de sua especulação filosófica.

Sobre a questão da técnica, a leitura a seguir se concentra em textos de Heidegger pós-1930, levando em consideração sobretudo o desdobramento das ideias do filósofo a partir do contexto político, cultural e intelectual da Alemanha entreguerras, no qual vinham à tona entusiasmadas reflexões acerca da técnica moderna4. O que se procura é compreender como Heidegger reconduz a questão da técnica a partir do que seria o seu aspecto mais essencial, orientando o pensamento para o âmbito privilegiado da linguagem.

\section{TÉCNICA, DESTINO E VERDADE}

A conferência de título "A questão da técnica" apresenta-se desse modo em 1953 na série As artes na Idade da Técnica, promovida pela Academia de Belas-Artes da Baviera. Heidegger palestrou na Escola Técnica Superior de Munique e a conferência foi publicada no ano seguinte. Conforme nos diz Rüdiger (2006), Heidegger apresenta as ideias que já vinha elaborando desde 1949, ano em que participa no Clube de Bremen de um ciclo de palestras denominado Lances de vistas sobre o que é (Einblick in das was ist). $\mathrm{Na}$

\footnotetext{
3. A respeito do modo como a técnica aparece em Ser e Tempo - não tematizada como questão, mas elaborada segundo seu caráter artesanal e instrumental, construindo a facticidade do ser do homem -, ver o artigo de Benedito Nunes, "História e ontologia (da essência da técnica)", de 2012.

4. É essa atmosfera, por exemplo, que recepcionará as ideias de Oswald Spengler e a publicação de sua obra A decadência do Ocidente, em dois volumes, de 1918 e 1922, obra cuja tiragem espantou o ambiente da intelectualidade em que Heidegger se fazia contemporâneo. As ideias de Spengler tematizam o entrar em cena do declínio do Ocidente no modo do declínio de sua cultura técnica. A era técnica inauguraria a decadência ocidental, produzindo os efeitos de um mundo marcado pela dominância do capital e da mecanização. Spengler nos dirá que o fenômeno das metrópoles, das modernas democracias como formas democráticas de efetivação do poder do dinheiro e, notadamente, o fenômeno da técnica que a todos engendra, são os sinais mais evidentes do declínio do mundo moderno, de uma irrefreável decadência e empobrecimento do espírito. Sobre a discussão, ver o livro de Rubem Mendes de Oliveira, A questão da técnica em Spengler e Heidegger (2006).
} 
ocasião, o filósofo apresentou a conferência intitulada Das Ge-stells (A com-posição), tendo como base as ideias que seriam ampliadas e desenvolvidas na conferência sobre a questão da técnica, publicada em 1954.

Na clássica pergunta pelo o que é a técnica, as primeiras respostas nos vêm a partir de uma determinação antropológica e instrumental da técnica, a qual é entendida comumente como atividade humana e articulação de meios para objetivos e fins; pertence a ela o universo dos instrumentos, utensílios e suas funções (HEIDEGGER, 2002a). Como se supõe correntemente, a instrumentalidade se determina na consecução de certos meios para alcance de certos fins, na qual um sentido de mediação pressupõe o efeito de sua aplicação, imperando aí a noção de causalidadé. Heidegger retorna à doutrina das quatro causas insistindo no questionamento do "que é, afinal, a causa; o que permitiria, de fato, a noção específica e a uniformidade das quatro causas em Aristóteles? (HEIDEGGER, 2002a, p. 13).

Segundo o filósofo, permanece velada a compreensão acerca do modo como as causas aristotélicas se relacionam reciprocamente. Permanece ainda por compreender, nesse caso, o sentido que o homem grego estabelece para a ideia de causa a partir da palavra aıtıov, ou "aquilo pelo

5. Veremos que, na conferência de 1953, Heidegger pergunta pela essência da técnica entendendo-a a partir da palavra Ge-stell, ou com-posição, palavra que já aparece em 1949. Resguardados os problemas sobre a tradução de Gestell, na realização de nosso trabalho seguimos a tradução do professor Emmanuel Carneiro Leão, endossada ainda por Irene Borges-Duarte. Levando em conta a opção dada por Marco Aurélio Werle em traduzir o termo por "armação", consideramos a palavra composição mais de acordo com o que Heidegger sugere a respeito da essência da técnica, isto é, que não é nada técnico este ou aquele equipamento ou ordenação, mas trata-se antes de um com-por, de um modo de ordenar e armar que enquanto põe é ao mesmo tempo com-posto e co-ordenado. Com-posição parece ressaltar o caráter de referência mútua entre o pôr - stell - da técnica e o modo de ser do homem como ser-aí o ser-no-mundo, isto é, com os outros, junto às coisas e consigo mesmo, o que se com-põe como possibilidade e disponibilidade, nos diz Heidegger (2015) em Ser e Tempo. Sobre o termo, ver ainda os estudos de Irene Borges-Duarte: "La tesis de Heidegger sobre la tecnica", Madrid, 1993, e "Gestell e Gestalt: fenomenologia da configuração técnica do mundo em Heidegger”, Évora, 2014.

6. Como aponta Heidegger a partir da Metafísica de Aristóteles, o ensinamento rigoroso da causalidade supõe a existência de quatro causas principais para tudo aquilo que é, a saber, uma causa material ou a matéria de que algo é feito, uma causa formal ou a forma inscrita na matéria, uma causa final ou o fim para o qual forma e matéria se determinam, e uma causa eficiente ou o ator/ação que produz e alcança o efeito de determinado fim. (HEIDEGGER, 2002a, p. 14) 
que um outro responde e deve" (HEIDEGGER, 2002a, p. 14). Nesse sentido, "as quatro causas são os quatro modos, coerentes entre si, de responder e dever" (HEIDEGGER, 2002a, p. 14). Mas o que quer dizer esse "responder e dever"? Heidegger nos diz que trata-se de um responder pelo "dar-se e propor-se" daquilo que converge e reúne as quatro causas, deixando algo aparecer lançado para uma vigência. Os modos de responder e dever são, em última análise, esse deixar-aparecer de algo que permanecia encoberto, mas passa à vigência segundo uma condução da articulação dos quatro modos de responder e dever.

A partir desse ponto, Heidegger aborda a noção platônica de produção ou poiésis ( $\rho o i n \sigma \iota \varsigma)$, como o nome grego dado a essa condução à vigência operada nos modos de responder. Assim, o sentido de causalidade mostra-se como um responder e dever que são os modos de relação das quatro causas manifestos através da produção. Seguindo o caminho interpretativo de Heidegger, produção e produzir, na representação do mundo grego, é o advir de algo próprio que cresce e passa do encoberto ao desencoberto, daquela não-vigência à vigência, que tanto pode eclodir por si mesmo

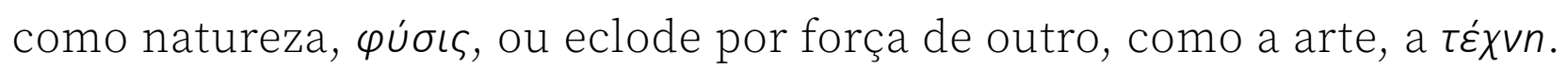

Aqui a argumentação heideggeriana sofre uma inflexão decisiva, pois, perguntando pela essência da técnica, chegou-se a um produzir que conduz algo do encoberto ao desencoberto, deixando assim vigorar e chegar um desencobrir. Mas esse desencobrir, por seu turno, mostra aquilo que

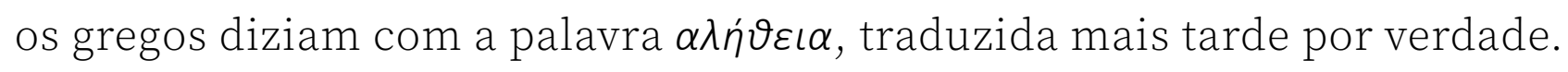
Trata-se do processo de desencobrimento fundamental que se nos aparece quando inquirimos a técnica a partir da sua instrumentalidade, que deixa revelar a causalidade e seus modos de responder e dever, deixando revelar a produção orientadora dos modos da causalidade, revelando aí o âmbito do desencobrimento, isto é, da verdade. Nas palavras de Heidegger: 
Onde nos perdemos? Questionamos a técnica e chegamos

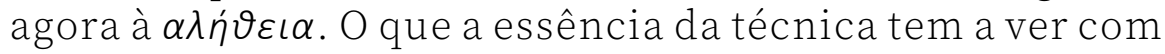
desencobrimento? Resposta: tudo. Pois é no desencobrimento que se funda toda pro-dução. (...) Se questionarmos, pois, passo a passo, o que é propriamente a técnica conceituada, como meio, chegaremos ao desencobrimento. Nele repousa a possibilidade de toda elaboração produtiva. A técnica não é, portanto, um simples meio. A técnica é uma forma de desencobrimento. (...) Trata-se do âmbito da verdade. (HEIDEGGER, 2002a, p. 17)

A reflexão sobre a técnica chega ao âmbito da verdade e por isso já não se pode restringi-la à perspectiva instrumental. Não se trata apenas de um meio para um fim, mas antes a técnica é entendida como forma que engendra e deixa vir à luz o desencobrir-se de algo, determinando-se, pois, por esse deixar desencobrir, por esse responder, e não por um operar e manusear dados na instrumentalidade da técnica. Para Heidegger, portanto, o decisivo na pergunta pela técnica não é o instrumental; o decisivo é o desencobrimento em jogo na essência da técnica, o decisivo é a relação original que se estabelece entre tékhne e alétheia.

A partir daí, interessa notar que, como técnica, a técnica moderna também se rege através do desencobrimento, mas trata-se de um outro modo de desencobrir distinto do modo de desencobrir da técnica artesanal, pois:

O desencobrimento, que rege a técnica moderna, é uma exploração que impõe à natureza a pretensão de fornecer energia, capaz de, como tal, ser beneficiada e armazenada. O subsolo passa a se desencobrir, como reservatório de carvão, o chão, como jazidas de minério. Era diferente o campo que o camponês outrora lavrava, quando lavrar ainda significava cuidar e tratar. (...) Hoje em dia, uma outra posição também absorveu a lavra do campo, a saber, a posição que dis-põe da natureza. E dela dis-põe, no sentido de uma exploração. (HEIDEGGER, 2002a, p. 18-19) 
Vemos então que o tipo de desencobrir da técnica moderna se dá no modo de um explorar que cumpre um processo de valer o máximo de rendimento no mínimo de gasto. O modo de desencobrimento da técnica moderna abre e expõe segundo um por, segundo uma situação que é um desafiar a natureza, um posicionar que quer extrair, que exige enquanto desencobre, exige e quer impelir adiante um proveito máximo a partir de um mínimo dispêndio. É essa a natureza do modo de desencobrimento da técnica moderna, nos diz Heidegger (HEIDEGGER, 2002a). Tem o caráter do desafio e como tal não se dá pelo deixar vigorar simplesmente - pensemos que no desafio sempre se é desafiado -, mas se impõe e desencobre na medida em que desencobre para si mesmo esse modo de desencobrir, isto é, de desafiar segundo uma ideia de segurança, direção, armazenamento, de um dispor de recursos e formas a serem transformados, mas sobretudo, controlados, estocados, repassados. Na explicação do filósofo:

Extrair, transformar, estocar, distribuir, reprocessar
são todos modos de desencobrimento. Todavia, este
desencobrimento não se dá simplesmente. Tampou-
co, perde-se no indeterminado. Pelo controle, o desen-
cobrimento abre para si mesmo suas próprias pistas,
entrelaçadas numa trança múltipla e diversa. Por toda
parte, assegura-se o controle. Pois controle e seguran-
ça constituem até as marcas fundamentais do desen-
cobrimento explorador. (HEIDEGGER, 2002a, p. 20)

O desencobrir da técnica moderna, portanto, se mostraria através do desafiar, de um dispor da exploração que desafia a natureza a se revelar como disponibilidade, como fundo de reserva em que tudo se controla e se assegura; nesse desafiar implica-se o desafiado. Retorna a questão: "Quem realiza a exploração desafiadora que des-encobre o chamado real, como dis-ponibilidade"? (HEIDEGGER, 2002a, p. 21). De novo temos o homem. Sabemos que ele é capaz de realizar e representar coisas de diferentes modos, numa 
"trança múltipla e diversa", mas de modo algum parece capaz de ter em seu poder o desencobrimento em si mesmo em que o real se mostra ou se retrai.

Somos convidados a pensar que o ente que é o homem parece não poder dominar o desencobrir, pois ele mesmo já foi desafiado para o desencobrimento. Assim, o desencobrir mesmo não pode ser feito do homem, domínio do homem. É preciso considerar que o ente humano participa do desencobrimento na medida em que se destina e atende ao apelo do desencobrir e, respondendo a este apelo, deixa ser o modo de desencobrir da técnica moderna, deixando vigorar aí a trama em que se enreda, por exemplo, na coisa da ciência (HEIDEGGER, 2002a, p. 22). Nas palavras de Heidegger:

O desencobrimento já se deu, em sua propriedade, todas as vezes que o homem se sente chamado a acontecer em modos próprios de desencobrimento. Por isso, des-vendando o real, vigente com seu modo de estar no desencobrimento, o homem não faz senão responder ao apelo do desencobrimento, mesmo que seja para contradizê-lo. Quando, portanto, nas pesquisas e investigações, o homem corre atrás da natureza, considerando-a um setor de sua representação, ele já se encontra comprometido com uma forma de desencobrimento. Trata-se da forma de desencobrimento da técnica que o desafia a explorar a natureza, tomando-a por objeto de pesquisa até que o objeto desapareça no não-objeto da disponibilidade. (HEIDEGGER, 2002a, p. 22)

No desencobrir da técnica moderna, está em jogo essa espécie de planificação do desencoberto como disponibilidade, como objeto. Aquilo pelo qual o real torna-se disponibilidade, segundo Heidegger, diz respeito à essência do modo de desencobrimento da técnica moderna, isto é, ao que o filósofo chamou Ge-stell, ou com-posição, o apelo de exploração que também desafia o homem a dispor do que se desencobre. Gestell diz respeito ao tipo de desencobrimento que rege a técnica moderna, mas que, em si mesmo, não é nada técnico. Não se trata de algo para fora da ação do 
homem, todavia não acontece decisivamente pelo homem ou apenas no homem. Gestell diz dessa espécie de força de reunião daquele pôr - stellen que impõe ao homem desencobrir o real como disponibilidade; o homem é antes desafiado e provocado na Gestell.

É nesse sentido que Heidegger nos diz que a essência da técnica, ou Gestell, põe o homem a caminho do desencobrimento que conduz o real à disponibilidade. Mas, prossegue Heidegger, esse "pôr a caminho" significa destinar (HEIDEGGER, 2002a, p. 22-23). Segundo o filósofo, destino é essa força encaminhadora que põe o homem a caminho do desencobrir, do deixar ser de uma vigência. O destino se apresenta, então, como força que encaminha. Por isso, através dele se dá a essência da história, através dele o desencobrimento do que é segue um caminho, se envia ao homem no modo da Gestell (HEIDEGGER, 2002a).

De acordo com Heidegger, o destino do desencobrir rege o homem, mas não se trata de fatalidade ou de coação. Reger não é determinar; muito pelo contrário. Para Heidegger, ser capaz de regência é propriamente o que traduz a liberdade do homem, pois ele só é livre nesse envio, nesse pôr-se a caminho, "fazendo-se ouvinte e não escravo do destino" (HEIDEGGER, 2002a, p. 27-28). Assim, o desencobrir, para Heidegger, relaciona-se com aquilo que é livre, que aclara o encobrir e cobrir da verdade do Ser. Nos diz ele:

Quando pensamos a essência da técnica, fazemos a experiência da com-posição como destino de um desencobrimento. Assim já nos mantemos no espaço livre do destino. Este não nos tranca numa coação obtusa, que nos forçaria uma entrega cega à técnica ou, o que dá no mesmo, a arremeter desesperadamente contra a técnica e condená-la, como obra do diabo. Ao contrário, abrindo-nos para a essência da técnica, encontramo-nos, de repente, tomados por um apelo de libertação. (HEIDEGGER, 2002a, p. 28) 
Se enviando como nosso destino, a Gestell de Heidegger carrega em si o perigo da dominância e, assim, do obscurecimento da verdade do Ser como velar e desvelar. No destino figura o perigo de sobreposição da composição que desencobre o real como disponibilidade, isto é, figura o perigo de o homem não saber interpretar o desencobrimento como tal. Conforme argumenta Heidegger, está em jogo um possível enrijecimento do desencobrimento do real como o disponível, fazendo crescer a aparência de que o homem é o "senhor da terra" (HEIDEGGER, 2002a, p. 29), aquele que planifica a disponibilidade e que responde por tudo aquilo que existe. Nessa sobreposição da força da Gestell, dá-se o perigo do próprio encobrimento do desencobrimento, isto é, de o espaço próprio de manifestação do desencobrimento tornar-se encoberto, velado.

Como vemos, o que se torna decisivo na argumentação de Heidegger é que ele não pretende seguir o rumo da crítica radical aos efeitos da técnica. De fato, o objetivo de Heidegger implica em superar o ambiente efusivo de sua época e as abordagens dicotômicas acerca do mundo moderno e da técnica, entendidos na cisão entre uma perspectiva apologética e uma perspectiva puramente negativa, pessimista. No caso de Heidegger, vemos que, em última análise, "a técnica não é perigosa (HEIDEGGER, 2002a, p. 30), não é a técnica por si mesma uma ameaça. Não seremos atacados pelas máquinas e equipamentos técnicos mortíferos - apesar da possibilidade real desse acontecimento. O perigo ronda, nos diz Heidegger, mas ele reside na essência da técnica, na Gestell, e a ameaça já se sobrepôs à essência do homem. O predomínio da força da composição ameaça vetar ao homem a possibilidade de uma experiência da verdade em seu sentido mais essencial (HEIDEGGER, 2002a).

Portanto, não se trata de negar absolutamente a força da composição 
que rege a técnica, mas de compreender necessariamente sua natureza ambivalente, radicada naquilo que nos sobrevém com a palavra alétheia, desencobrimento. Por um lado, o compor que rege o humano expõe e faz emergir o real para o desencoberto; por outro lado, a dominância de sua força é capaz do dispor explorador da técnica moderna, do encobrir do desencobrir. Por isso nos soa através de Heidegger os famosos versos de Hölderlin, da elegia Pão e Vinho (1800-1801): "onde mora o perigo, é lá que também cresce o que salva” (HÖLDERLIN apud HEIDEGGER, 2002a, p. 31). Salvar, nos diz o filósofo, é chegar à essência deixando que ela apareça em seu brilho; por isso a tarefa do filósofo é a de meditar sobre a essência da técnica, pois nela cresce, isto é, deita raízes, mede e prospera aquilo que salva (HEIDEGGER, 2002a, p. 31).

Nesse sentido, a filosofia heideggeriana permanece perguntando por essa espécie de força que põe o homem a caminho de um desencobrimento explorador que, ao mesmo tempo que o ameaça, é capaz de redimi-lo, salvá-lo. Heidegger nos sugere que é preciso pensar o âmbito da composição que rege a técnica como perigo, mas, fundamentalmente, como esteio em que deitam as raízes daquilo que salva. "Na condição de destino, a vigência da técnica [como Gestell] impõe ao homem entrar no que ele mesmo não pode por si mesmo nem inventar e nem fazer" (HEIDEGGER, 2002b, p. 34) e, nesse sentido, pensar a essência da técnica deve nos levar àquilo que ultrapassa o técnico; deve nos remeter ainda uma vez mais para "o mistério de todo desencobrimento, isto é, da verdade" (HEIDEGGER, 2002a, p. 35). 


\section{O HORIZONTE DA LINGUAGEM}

A essência da técnica como Gestell revelou a relação que se estabelece entre técnica e verdade, entre a chegada de uma vigência e desencobrir do ente e o eterno encobrimento do Ser ele mesmo. Sendo capazes de ver o eterno encobrimento naquilo que se desencobre, o ser da verdade nos tem como destinatários. Para Heidegger, nesse destinar, impôs-se a necessidade de pensar, não tanto a dominância do técnico e sua aparelhagem, por assim dizer, mas a essência da técnica e sua capacidade de abrigar o que nos diz respeito, e de nos endereçar segundo o vir a ser desses "tipos irreais" que o homem cria para si, como nos diz Ortega y Gasset (ORTEGA Y GASSET, 1963, p. 33) e, bem antes, podemos acrescentar, Nietzsche (2004).

Conforme as ideias de Heidegger, reside ainda na destinação o caráter comum e a coimplicância entre técnica e ciência, erigidas segundo aquela ação de exigência, de demanda. A mesma provocação na ciência se mostra na técnica moderna, impondo à natureza a exigência de responder, de fornecer energia no sentido de capturá-la, de pô-la à disposição. Aparece aqui o nexo que liga ciência moderna e técnica moderna, ou seja, aquilo que Heidegger chamou de "intimação provocante" (HEIDEGGER, 1995, p. 25) abrigada na essência da técnica. Nessa atenção, percebeu-se que há algo envolvido na exigência e provocação da técnica que ultrapassa o homem e o deixa perplexo e impotente frente ao que se chamou o "irresistível da dominação tecnológica” (HEIDEGGER, 1995, p. 27).

Mas afinal, o que é isso que provoca, que reúne numa intimação provocante? A pergunta pela essência da técnica nos mostra que o homem é ele mesmo o intimado a responder a essa espécie de exigência da exigência; é antes o homem que é intimado a provocar a natureza, e a essa intimação não pode faltar. Mas por que o homem não pode faltar? O que 
há com ele para que se deixe provocar para a provocação? No curso dessas interrogações, Heidegger parece virar-se em direção à linguagem como fundamento que permite esse provocar, como aquilo a que o homem pertence, e nesse pertencer é capaz da provocação que desencobre o real.

Desde a Antiguidade há a noção de que o homem é o ser capaz da palavra ou da linguagem. O dito quer dizer, segundo Heidegger (1995), que é a linguagem que permite ao homem ser esse ser que é, enquanto homem. Como ser de linguagem, ele se determina em uma língua. Mas o que se entende correntemente por língua? O que é o falar da língua? Conforme a elaboração heideggeriana, poderíamos enumerar, de acordo com o senso comum: 1- falar é uma capacidade, atividade do homem, 2- falar diz respeito ao funcionamento dos órgãos de fonação e audição, 3- falar é expressão da alma, 4- falar é representar o real e o irreal (HEIDEGGER, 1995, p. 31). Segundo Heidegger, Humboldt aparece como o desenvolvedor de algumas dessas teses corretas, embora prematuras, sobre o domínio da língua:

Quando na alma desperta verdadeiramente o sentimento de que a língua não é simplesmente um meio de troca com vista ao acordo recíproco, mas que ela é um verdadeiro mundo que o espírito é obrigado a pôr entre si e os objetos pelo trabalho interno da sua força, então ela (a alma) está no bom caminho para se encontrar sempre mais nela (a saber, na língua como mundo) e a investir-se nela. (HUMBOLDT apud HEIDEGGER, 1995, p. 31-32)

Heidegger apresenta dois sentidos para a frase de Humboldt, um positivo e outro negativo. O sentido positivo diz respeito a uma ideia da língua como visão de mundo, como expressão do povo que a fala, dizendo respeito a uma espécie de mundo interposto entre o espírito eminentemente criativo e os objetos de uma realidade que é histórica. O sentido negativo da frase diz do fato da língua não ser apenas instrumento de comunicação. Devemos nos deter nessa restrição, pois, conforme vimos, pensando 
o horizonte da técnica moderna, o que se dá é justamente o contrário da delimitação indicada. Na era da dominação da técnica moderna, a língua é informação, é nada além de um instrumento de comunicação. Mas, se é assim, em que medida pode a língua transformar-se em informação por efeito da técnica? Será a língua também tão particularmente exposta à dominação da técnica? (HEIDEGGER, 1995). Que relação se estabelece entre técnica e língua? Parece que nessa altura são essas as perguntas fundamentais de Heidegger. Para respondê-las, o filósofo se propõe a buscar uma definição mais acertada do que seja próprio da língua, o que é o falar do homem e o que é a informação.

Demarca-se o falar como diferente do dizer. As pessoas podem falar muito e não dizer nada. O dizer é Sagan (HEIDEGGER, 1995, p. 34), significa mostrar, levar uma coisa a aparecer. Mas também pode ser entendido como o simples dar sinais, uma mensagem, uma instrução, um comando, se quiser. Esse seria o princípio que dirige os códigos informativos com os quais operam as máquinas, e é o mesmo que dirige e permite a ideia e o uso de computadores gigantes, o mesmo que nos permite perguntar pelo modo como a técnica interpõe-se à língua, pois exige dela a univocidade dos sinais. Aqui nota-se a intuição de Heidegger de que é a língua que parece regular os objetivos da máquina. A univocidade dos sinais de que depende a máquina só poderia ser dada pelo poder da língua, do mesmo modo que só nela pode acontecer o poema, algo que em princípio não se poderia programar em sinais fechados (HEIDEGGER, 1995).

A língua nos daria os indícios de que o dizer que a envolve ultrapassa o dizer da língua da técnica. Nesse sentido, e conforme nos indicou a noção de Gestell, o perigo que nos ronda reside então na sobreposição da língua da técnica sobre o dizer mais original abrigado na língua, reduzindo o efeito da palavra à informação rápida e eficiente, obscurecendo o poder 
da língua de ser capaz do não-controle, do não-domínio, atentando aí para o que se mostrou como o ser da verdade. Nos diz Heidegger:

Com a dominação absoluta da técnica moderna cresce o poder - tanto a exigência como a eficácia - da língua técnica adaptada para cobrir a latitude de informações mais vasta possível. É porque se desenvolve em sistemas de mensagens e de sinalizações formais que a língua técnica é uma agressão mais violenta e perigosa contra o caráter próprio da língua, o dizer como mostrar e fazer aparecer o presente e o ausente, a realidade no sentido mais lato. (HEIDEGGER, 1995, p. 37)

Na dominação pela técnica, a língua se converte em sinais e seu poder de univocidade garante o que chamamos de informação ampliada, rápida e eficiente. Essa mesma concepção se projetaria também na vida humana, tudo entrando na interpretação técnica, nos diz Heidegger (HEIDEGGER, 1995); tudo está restrito à correspondência da língua com um conjunto de mensagens e sinais. Todavia, aqui há um limite; o limite é dado pela língua natural. Até mesmo os sinais são elaborados dada uma língua natural.

A língua natural é a que permanece possibilitando toda transformação técnica. Língua natural é a língua corrente não tecnicizada, é a língua de tradição, nos diz Heidegger. A tradição deve ser interpretada, nesse sentido, como aquilo que preservaria um tempo inicial; nela se preserva o inaudito e o não formulado daquilo que foi dito e, nela, aquilo que não se disse se transforma em dádiva. Pela língua da tradição a própria tradição se mantém, nela se dá a língua natural como possibilidade de deixar aparecer o ainda não percebido no dito. É preciso que pela língua da tradição se diga novamente o mundo naquilo que se conserva no dito. Eis aí a missão dos poetas.

A noção dos dois tipos referidos de língua, a da tradição e da técnica, representa mais que uma oposição, nos dirá o autor, representa a 
própria ameaça perigosa à essência do homem. Pelo fato de a língua já se ter tornado dupla, prova-se a ameaça e o obscurecimento que nos ronda. Essa oposição marca o acontecimento que agora domina o homem, que se vê diante de um mundo tecnicizado no qual tudo se constrói e se dispõe, e a isso assiste "coberto pelas últimas informações" (HEIDEGGER, 1995, p. 41). Seria preciso, portanto, meditar sobre nossa condição e buscar na língua natural - único lugar possível, pois é morada do dizer - a capacidade permitida ao homem de vislumbrar o desencobrir em seu sentido mais originário, podendo conduzir-se a um só golpe, à experiência do dito e do silêncio e à proximidade do "inefável” e do inexprimível (HEIDEGGER, 1995, p. 42) 7 .

Perguntando pela questão da técnica, nos deparamos agora com o modo através do qual a língua é capaz de resistir à dominação técnica. Mas como é possível essa resistência? O que há com a língua? A partir do desenvolvimento da argumentação heideggeriana, vemos o modo como a língua torna-se cindida e, a um só tempo, é porosa à dominância da técnica, transformando-se em informação, e também a ela resiste, na medida em que se sobrepõe como língua natural, como palavra que inaugura mundo. A posição de Heidegger é que nessa ambivalência da língua, diante da dominação técnica, fala a linguagem. Mas como isso? Aqui entra em jogo a busca pela essência da linguagem, e pela distinção mais rigorosa entre o falar, a língua e a linguagem à luz da verdade do Ser.

7. No horizonte dessa experiência se inscrevem os escritos de Heidegger reunidos em Caminhos de Floresta (Holzwege), obra publicada em 1950. Sobre Holzwege, ver o texto de Ernildo Stein, "O incontornável como o inacessível: uma carta inédita de Martin Heidegger", de 1999.

8. Trata-se aí do centro das discussões da chamada virada (Kehre) de Heidegger, discussões que permitiram falar em um Heidegger I e II, como popularizado na obra de W. J. Richardson, "Heidegger, through phenomenology to tought", publicada em 1963. Sobre essa classificação, ver especialmente a parte II, Reversal, e o capítulo XVI, Language, incluído na seção b da parte III. Sobre o tema e o modo como o próprio Heidegger entende sua "kehre", ver também o artigo de L.P. Hemming, "Speaking out of Turn: Martin Heidegger and die Kehre", de 1998. 
Vimos que, na acepção corrente, falar é expressão e comunicação acompanhadas de pensamento, diz respeito a um interior que se exterioriza, à expressão da alma humana em sons. Falar também é entendido como comunicar, como atividade humana; o homem fala uma língua, e, se assim é, quem fala é o homem. Considerando essa acepção, não poderíamos dizer, como dissemos, que a linguagem fala. Todavia, como nos diz Heidegger, a linguagem fala e só então o homem fala uma linguagem (HEIDEGGER, 2012a).

Acompanhando a argumentação do filósofo, encontraríamos essa fala da linguagem naquilo que se diz. Porém, como vimos, o que traz a fala à linguagem parece não se esgotar no dito qualquer. A linguagem fala apenas no dito genuíno, no não-dito no dito, no dizer genuinamente; "dizer genuinamente é dizer de tal maneira que a plenitude do dizer, própria ao dito, é por sua vez inaugural" (HEIDEGGER, 2012a, p. 12). Chegando ao ponto central da interpretação de Heidegger, o dizer genuinamente como dizer inaugural é o que se diz no poema "Uma tarde de inverno", de Georg Trakl:

Da janela a neve cai,

Prolongado soa o sino da tarde.

Para muitos a mesa está posta

E a casa bem servida

Alguns viandantes da errância

Chegam até a porta por veredas escuras.

Da seiva fria da terra

Surge dourada a árvore dos dons.

O viandante chega quieto;

A dor petrificou a soleira.

Aí brilha em pura claridade

Pão e vinho sobre a mesa. (TRAKL apud HEIDEGGER, 2012a, p. 12) 
A partir do poema é que Heidegger pergunta sobre a experiência com a linguagem, quer saber como pode ser que a linguagem, e não o homem, fale. "O que procuramos se encontra, portanto, na poética do que se diz" (HEIDEGGER, 2012a, p. 14). A fala do poema nomeia uma tarde de inverno qualquer. Mas esse nomear não seria simplesmente atribuição de uma palavra à coisa. Na interpretação de Heidegger, nomear é evocar para a palavra e essa evocação é sempre antes uma provocação e uma invocação (HEIDEGGER, 2012a). O que se provoca é a vigência, a proximidade do que vige, e o que se invoca é a ausência, a distância que envolve o evocado.

O que o filósofo nos diz é que essa evocação do nomear sustenta, no fundo, ao mesmo tempo uma presença e uma vigência do que se ausenta. No poema de Trakl, o que se fala não é sobre uma tarde que se passou numa data histórica que existiu para o poeta, ainda que possa ter havido uma tal tarde. Aí não importa, de modo algum, se algum homem em especial viu a tarde. A tarde de que nos fala o poeta não está aqui, presente agora, mas distancia-se quando evocada para a proximidade, deixando vir na linguagem a poética do poeta, isto é, aquilo de impronunciável que, no entanto, dirige o curso da "errância" e da "quietude" do viandante, como soa nos versos de Trakl.

O que chama a atenção, portanto, é esse nomear visto na fala poética, o nomear que evoca enquanto convoca e invoca. A nomeação que evoca chama as coisas para a proximidade do homem, para vigorar enquanto ausência, e esse chamar é convidar as coisas para que possam, como coisas que são, concernir aos homens. Evocando a tarde de inverno, o poeta mostra o que concerne ao homem, convidando-o à familiaridade e ao pão, à estranheza e à dor. O nomear da neve convida céu e terra, o nomear do sino convida humano e divindade. Heidegger diz que esses quatro elementos originários são a unidade de ser, "quadratura" originária de mundo 
(HEIDEGGER, 2012a, p. 16).

A ideia é que as coisas assim nomeadas, ou seja, evocadas, deixam tal quadratura originária perdurar nelas. E, nesse perdurar da quadratura, que faz das coisas coisas, dá-se o mundo. "Fazendo-se coisas", a cada momento de sua evocação, as coisas dão suporte ao mundo, "des-dobram mundo" (HEIDEGGER, 2012a, p. 17). Suportar, dar suporte tem proximidade etimológica com as palavras portar, porte, gesto, nos diz Heidegger. Assim, "fazendo-se coisa, as coisas são gesto do mundo" (HEIDEGGER, 2012a, p. 17).

Portanto, a primeira estrofe do poema não nomearia somente coisas - neve, janela, sino, mesa e casa -, nomearia mundo. A estrofe fala e chama as coisas para virem com seu mundo à presença dos homens, notando aquilo que se abriga na ausência. Desse modo, importa notar que, como guardião da experiência do desencobrir mais original da linguagem, é, pois, o poeta aquele capaz de não sucumbir a certo excesso de luminosidade da exigência técnica. Heidegger nos diz que o poeta não se ajusta completamente à língua da técnica, pois, desde o início, fala segundo essa saga do dizer mais original, segundo a fala da linguagem que conduz o pensamento ao velar e desvelar constitutivo da verdade, do ausente e presente que conformam o real.

Considerando o horizonte da técnica moderna e o sentido originário da linguagem no dizer genuíno do poeta, Heidegger ainda deve retomar a pergunta da elegia de Hölderlin, "Pão e Vinho": "para quê poetas em tempo indigente?" (HEIDEGGER, 2012b, p. 312). A partir do horizonte da época, interessa perguntar ainda uma vez que indigência é essa de que nos fala Hölderlin (HEIDEGGER, 2012b, p. 309). O tempo referido por Heidegger é "a era do mundo à qual nós ainda pertencemos” (HEIDEGGER, 2012, p. 309), isto é, a era da técnica e o mundo moderno, sendo a indigência a falta má- 
xima que sustenta esse tempo. Segundo a poesia de Hölderlin, avança a noite do mundo, os deuses partiram, a trindade Héracles, Dionísio e Cristo já não mais se encontra presente, dá-se a falta completa da divindade. Já não há, na escura noite do mundo, um deus que possa reunir em si, "visível e univocamente, as pessoas e as coisas e que, com base nessa reunião, articule a história do mundo e a estância humana nessa história" (HEIDEGGER, 2012b, p. 309).

É esse o âmbito da indigência da noite do mundo, o tempo da fuga dos deuses e da incapacidade de notar que tal fuga é uma falta; nisso consistiria a máxima indigência, se assim podemos dizer. Na noite que avança, apaga-se na história do mundo "o fulgor da divindade" (HEIDEGGER, 2012b, p. 310), retira-se o fundo sobre o qual o mundo se dá, convertendo-o em representação, imagem, objeto, disponibilidade. Por isso, nos diz Heidegger: "A era do mundo, que carece de fundamento, encontra-se suspensa no abismo" (HEIDEGGER, 2012b, p. 310).

Mas, se o mundo se encontra suspenso no abismo nessa era do mundo, há que se suportar o abismo, ser capaz dele. Para Heidegger, se supormos que é possível uma viragem para esse tempo indigente, ela só poderia se dar se o mundo virasse a partir do abismo. O que isso quer dizer? Seguindo o caminho poético de Hölderlin, chegamos ao ponto decisivo de uma propriedade que estabelece o poeta como aquele capaz de suportar e experimentar o abismo, Ab-grund, o fundo sem fundo das coisas que são. Segundo os versos de Hölderlin, citados por Heidegger:

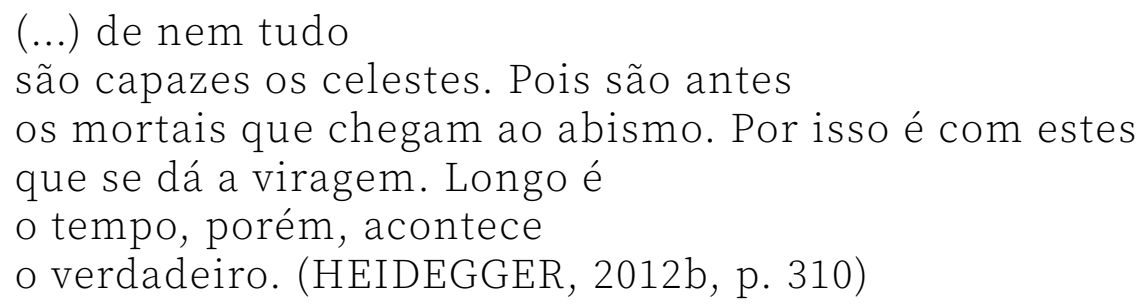


Na longa noite do mundo, isto é, em nossa época marcada pela dominância da técnica e pela conversão do mundo em imagem, é o poeta aquele capaz de engendrar a viragem. Suportando o abismo, deve ser capaz de superar o pensamento calculador em proveito do pensamento que deixa vir à linguagem a fala dela própria, isto é, a ressonância da verdade do Ser a partir do ser da verdade como desvelar e velar. Longo é o tempo da espera do poeta, porém, acontece o verdadeiro, nos diz Hölderlin, e com ele a viragem.

Segundo Heidegger, o poeta se distingue e realiza sua experiência genuína com a linguagem na medida de uma cara e necessária renúncia, que aqui é mencionada e acontece quando o poeta se vê frustrado na busca da palavra que contemple aquilo que o interpela; frustrado, assume-se nessa condição e renuncia seu desejo, a expectativa dessa busca. Tal renúncia parece tratar de um abrir mão do modo habitual de se pensar sobre a linguagem. Uma renúncia ao modo de relacionar palavra e coisa, de se relacionar com palavra e coisa enquanto se é poeta, o qual renuncia ao modo da procura obstinada regida pela racionalidade, pela procura do dizer certa coisa através de certa palavra que a essa mesma coisa corresponda. Essa renúncia abre ao poeta a possibilidade da experiência com a linguagem. O poeta vai aprender que não existe coisa alguma que seja antes ou fora da palavra (HEIDEGGER, 2012a), pois em verdade é ela quem interpela, quem evoca coisa, quem chama o poeta a dizer. A palavra da linguagem arrebata-o, devora-o para que ele anuncie, de forma inédita, alguma coisa que pode ser coisa junto dele.

Assim, a palavra, essa que fala desde a linguagem, confere sentido à coisa, seu nomear é uma evocação, um chamado para que a coisa seja a coisa que é diante do homem, uma convocação para que se apresente como coisa que, enquanto é, enquanto vigora, se dirige ao homem e se consti- 
tui como coisa, constituindo assim o mundo onde ele habita e é homem. A experiência do poeta, então, a partir de sua renúncia, permite que ele anuncie de forma nova (reanuncie) seu ofício e sua descoberta. Não mais a tentativa de boa travessia de uma coisa a uma palavra que a conforme, mas agora ele mesmo foi atravessado pela verdade da palavra. Depois de um longo caminhar à procura da palavra que se pensava ter abandonado a coisa, o poeta recebe de seu destino a notícia: nada pode ser encontrado enquanto se quer achar o que, no fundo, se pensa possuir por intermédio da razão. O aprendizado dessa revelação o faz experimentar o abismo, sendo capaz de renunciar a si mesmo e a seu antigo mundo dado pela relação que outrora também acreditava valer entre coisa e palavra - relação forçosamente polarizada que, no entanto, vela, esconde e retém o sentido da verdade que nos chega pela palavra da linguagem.

Seja como for, pelas passagens de Heidegger, apreendemos que a dominância da língua da técnica se sobrepõe e acossa o poeta, mas, para ele, no dizer genuíno, ainda lampeja o segredo original abrigado na língua. Pelo aprendizado da renúncia, o poeta compreende que à revelia de esforço, arranjo, manejo, não se pode calcular o poema, represar a palavra, medi-la, engessá-la, restando o mistério do que fala pela linguagem como fulgor de algo impronunciável. No horizonte da superação da metafísica, vemos que Heidegger orienta seu pensamento para a linguagem, procurando, todavia, ultrapassar a concepção moderna que envolve a linguagem como técnica ou como domínio da lógica proposicional. Antes, a linguagem deve ser compreendida em seu sentido mais essencial e originário.

Dedicando-se a essa compreensão da linguagem, segundo Heidegger, o homem tornar-se-ia capaz daquilo que o filósofo chamará serenidade (gelassenheit) (HEIDEGGER, 1959), isto é, capaz de rever na essência da técnica a ambivalência fundamental que a dirige e que deve dirigir o homem a um sim e um não na época da dominância da técnica e suas tec- 
nologias. Pelo dizer do poeta, deve ser possível repensar a técnica segundo os limites vislumbrados na fala da linguagem, isto é, segundo os limites próprios daquilo que concerne ao homem em seu modo de ser homem, esse ente que, por força da linguagem, é capaz de corresponder a tékhne e a díke, é capaz da razão que calcula e do pensamento que medita.

\section{CONSIDERAÇÕES FINAIS}

Conforme as ideias de Heidegger, devemos ter em conta o que nos vem ao pensamento através das indicações da palavra grega tékhne. Com ela nos chega a noção de um saber, de um modo de desencobrir que envolve um tipo de visão fundamental, isto é, um tipo de saber que se torna princípio de permanência e consistência. O saber da técnica deixaria ver o próprio Ser em ação como este ou aquele ente (HEIDEGGER, 1978). A partir de Heidegger, podemos dizer que a técnica deve ser pensada segundo um deixar ver e fazer aparecer o Ser no ente.

Daí, figura para o homem, segundo sua pré-compreensão de ser, a possibilidade de uma instauração vigorosa capaz de engendrar a si mesma numa aplicação de múltiplas habilidades, ou numa identificação total com os entes, vigentes segundo um vigor que a instauração vigorosa mesmo não domina. A aparente identificação imediata com o domínio ôntico, ou essa identificação absoluta com o universo de nossos utensílios e arranjos que nos vêm à luz no desencobrimento, tem nos impedido da possibilidade de refletir sobre a instância em que a instauração vigorosa se agita, impede de pensar a partir de onde o vigor não é dominado pelo homem, mas o atravessa e o toma, instaurando-se.

Ultrapassando os aspectos antropológicos e instrumentais, o fundamento da técnica é a força de reunião, Gestell, que é capaz de engendrar o desencobrimento do real como disponibilidade, como objeto à disposi- 
ção do homem. Como Gestell, reside na técnica o perigo de sobrepor-se à essência do homem, velando o âmbito especial a partir do qual se torna possível todo desvelamento, desencobrimento, todo manifestar-se do ente. Estamos ameaçados na medida em que esse âmbito aberto, que torna possível o desencobrimento, é como que soterrado pela verdade do ente tornada objetividade. O perigo, portanto, é a ameaça de se vetar ao homem a possibilidade de experimentar a própria "verdade do Ser ou o ser da verdade", nos diz Heidegger (HEIDEGGER, 2012, p. 124).

Como herdeiros da técnica moderna, nós contemporâneos somos atravessados por essa sobreposição, pelo império da tecno-logia, isto é, da colonização e planificação absoluta do pensar que reúne - legein -, transformado doravante em desencobrimento explorador, assegurador, controlador (HEIDEGGER, 2012, p. 333). Mas, onde impera o perigo supremo, isto é, na força de Gestell, reside e cresce o que poderia salvar o homem na noite do mundo, como nos diz Hölderlin. Salvar, na interpretação heideggeriana, se impõe como preparar o caminho, atentar-se para o núcleo dessa força, sopesando aquilo que por ele e dele provém como desencoberto. Esse núcleo nos fala do âmbito do desencobrir original, identificado na palavra grega alétheia. Tal desencobrir só pode ser resguardado e cuidado pela linguagem no modo da língua natural, isto é, a língua que sustém e mantém a própria possibilidade da língua da técnica e sua dominação.

De acordo com Heidegger, vimos que a linguagem mesma, enquanto horizonte instaurador de toda Gestell, seria capaz de nos indicar e preparar o caminho para o cumprimento de nosso destino, expondo o homem aos limites do disponível e ao mistério do incontornável. É pela linguagem que o poeta seria capaz de deixar ver o âmbito do aberto em que o desencobrir original opera. Para Heidegger, Trakl e Hölderlin, por exemplo, dão o testemunho desse deixar vir à luz em meio ao frenesi moderno do manifesto, 
do controlado, do calculado. No enfretamento de cada época é, pois, o poeta aquele que poderia dizer do essencial, do inaudito no dito (HEIDEGGER, 2012b).

Desse modo, podemos dizer que assim como perigo e salvação coabitam a dominância da Gestell, o pensador, o poeta e o técnico só podem ser como cada um é porque coabitam a região misteriosa da linguagem onde vigora todo desencobrimento. Todavia, na morada que é a linguagem (HEIDEGGER, 2012a), caberia ao poeta, que guarda o segredo oculto da palavra, a tarefa de encaminhar o pensar, isto é, de poder direcioná-lo ao que Heidegger chamou uma "profunda consonância com o que propriamente acontece na história de um povo” (HEIDEGGER, 1978, p. 39), permitindo, na escuta do destino, a escuta da verdade.

Por fim, diante da dominância da técnica, Heidegger desejou gestar um novo pensar a partir da escuta da palavra poética. Como encaminhamento deste texto, resta retomar a questão da técnica na atenção ao mundo contemporâneo e ao âmbito próprio da filosofia. Se é o poeta - e não tanto o cientista - aquele que pode dizer da verdade de todo desencobrir, sendo capaz do abismo e do dizer genuíno, de que modo e por onde falam os filósofos na era da técnica e suas tecnologias? Seguindo as passagens de Heidegger, chega-se a um ponto ainda por esclarecer: o que cabe ao filósofo na era das tecnologias de controle, de energia atômica, de automação, de informação, de genes? Será que aquele que se dedica à filosofia já se converteu em técnico, divulgador científico, poeta? Ou, no fundo, frente à dominância da técnica, a filosofia se embrenha a caminho do novo pensar através de sua natureza política? 


\section{REFERÊNCIAS:}

BORGES-DUARTE, I. Gestell e Gestalt: fenomenologia da configuração técnica do mundo em Heidegger. In: BORGES-DUARTE, I.; PARDELHA, I (org.). Fenomenologia e Ciência. CONGRESSO INTERNACIONAL DA AFFEN, 4., 2014, cidade. Actas. Disponível em: [http://www.affen.pt/iv-congresso-internacional-da-affen.-iii-congresso-luso-brasileiro-de-fenomenologia. html]. Acesso em: [4 out. 2018].

La tesis heideggeriana acerca de la tecnica. Anales del Seminario de Historia de la Filosofia, Madrid, n. 10, p. 121-156, 1993.

HEIDEGGER, M. Serenidade. Lisboa: Instituto Piaget, 1959.

introdução à Metafísica. Rio de Janeiro: Tempo Brasileiro, 1978.

A constituição onto-teológica da metafísica. In: HEIDEGGER, M. Conferências e escritos filosóficos. 4. ed. São Paulo: Nova Cultural, 1991. p. 149-162.

Vega, 1995.

Lingua de tradição e língua técnica. Trad. Mário Botas. Lisboa: Press, 1996.

Hölderlin's hymn "The ister". Bloomington: Indiana University

A questão da técnica. In: Ensaios e Conferências. Petrópolis: Editora Vozes, 2002a. p. 11-38.

O que quer dizer pensar? In: Ensaios e Conferências. Petrópolis: Editora Vozes, 2002b. p. 111-124.

A essência do fundamento. In: Marcas do Caminho. Petrópolis: Vozes, 2008. p. 134-188.

A caminho da linguagem. São Paulo: Vozes, 2012a.

Para quê poetas? In: Caminhos de Floresta. Lisboa: Fundação Calouste Gulbenkian, 2012b. p. 307-367.

Ser e tempo. Petrópolis: Editora Vozes, 2015.

HEMMING, L. P. Speaking out of Turn: Martin Heidegger and die Kehre. International Journal of Philosophical Studies, Abingdon-on-Thames, v. 6, n. 3, p. 393-423, 1998.

NIETZSCHE, F. A origem da tragédia. 12.ed. Lisboa: Guimarães Editores, 2004. 
NUNES, B. História e Ontologia (da essência da técnica). Ekstasis: Revista de Hermenêutica e fenomenologia, Rio de Janeiro, v. 1, p. 225-237, 2012.

OLIVEIRA, R. M. A questão da técnica em Spengler e Heidegger. Belo Horizonte: Tessitura, 2006.

ORTEGA Y GASSET, J. Meditação da técnica. Rio de Janeiro: Livro Ibero Americano, 1963.

RICHARDSON, W. J. Through Phenomenology to Thought. New York: Fordham University Press, 2003.

RÜDIGER, F. Martin Heidegger e a questão da técnica: prospectos acerca do futuro do Homem. Porto Alegre: Editora Sulina, 2006.

SÓFOCLES. Antígona. Trad. Luis Gil. Espanha: Debolsillo, 2009.

SPENGLER, O. A decadência do Ocidente: esboço de uma morfologia da História Universal. Rio de Janeiro: Zahar Editores, 1982.

STEIN, E. O incontornável como o inacessível: uma carta inédita de Martin Heidegger. Revista Natureza humana, São Paulo, v. 1, n. 2, p. 231-250, 1999.

WERLE, M. A. Heidegger e a produção técnica e artística da natureza. Revista Trans/Form/Ação, Marília, v. 34, p. 95-108, 2011. 